\title{
Correspondence
}

To the Editors

\section{COVID-19 pandemic, schooling and hyper-protectionism}

Sri Lanka Journal of Child Health, 2021: 50(2): 367

DOI: http://dx.doi.org/10.4038/sljch.v50i2.9595

(Key words: Covid-19 pandemic, schooling, children, hyper-protectionism)

Dear Editors,

Schooling for children during COVID-19 pandemic is an important issue in clinical paediatrics ${ }^{1}$. Adduci $\mathrm{A}$, et al ${ }^{1}$ mentioned that "It is hard to strike the right balance between institutions struggling to establish a set of rules to ensure.... that are fundamentally important to our patients".

The school closures during COVID-19 lockdown can result in several effects ${ }^{2}$. The important question is whether school closure can actually reduce the COVID-19 outbreak problem. In spite of a lack of major clusters of the disease emanating from schools, paediatric infection still occurs. Living at home or within a ward does not mean that there will be no chance that the children will not get disease. For the cancerous patient, living anywhere is still a risk due to impaired immunity.

The change from classic schooling to the new normal of tele-schooling is interesting. For good childhood development, interaction is needed. Such interaction is an important factor for child development and educational outcome ${ }^{3}$. It is questionable whether 'virtual' interaction can help develop educational targets or not. For example, it is not possible to control the attention of the children during a study session. As it seems that the new normal has to remain for a very long time, it is necessary to have an urgent study to assess the effect of neuro-psychological development of children under tele-schooling.

Finally, there is a simple question, "Is a school closure for preventing COVID-19 hyperprotectionism?" We would like to draw attention to one of the reasons that the new COVID-19 vaccine is not recommended for children, which is that children have a low risk of developing severe disease. If the paediatric population is at low risk, why do we have to hyper-protect? Indeed, we might not be hyper-protecting our children because of their risk to be damaged by the infection but to prevent them from transmitting the disease to parents and grandparents. Nevertheless, we don't have enough information to know whether a vaccinated person can still transmit the virus.

\section{References}

1. Adduci A, Ferrari A, Grampa P, Giovanetti M, Massimino M. How the COVID-19 pandemic has prevented children with cancer from pursuing their schooling in hospital or at home. Child's Nervous System 2021; 37:727-8.

https://doi.org/10.1007/s00381-020-

05027-1

PMid: 33438086 PMCid: PMC7802818

2. Wiwanitkit V. School closure, COVID-19 and influenza A. Pediatric Pulmonology 2020; 55(10): 2501.

https://doi.org/10.1002/ppul.24972

PMid: 32720757

3. Phillips DA, Lowenstein AE. Early care, education, and child development. Annual Review of Psychology 2011; 62: 483-500. https://doi.org/10.1146/annurev.psych.031 809.130707

PMid: 20822436

\author{
*Rujitika Mungmungpuntipantip ${ }^{1}, \quad$ Viroj \\ Wiwanitkit $^{2}$ \\ ${ }^{1}$ Private Academic Consultant, Bangkok Thailand \\ ${ }^{2}$ Honorary Professor, Dr. DY Patil University, \\ Pune, India \\ *Correspondence: rujittika@gmail.com \\ iD https://orcid.org/0000-0003-0078-7897
}

Open Access Article published under the Creative Commons Attribution CC-BY (c) (i) License 